Mrtchell, P. (1953). J. gen. Microbiol. 9, 273-287.

\title{
Transport of Phosphate across the Surface of Micrococcus pyogenes: Nature of the Cell 'Inorganic Phosphate'
}

\author{
By P. MITCHELL \\ Department of Biochemistry, University of Cambridge
}

\begin{abstract}
SUMMARY: An osmotic barrier, impermeable to inorganic phosphate ions, is present near the external surface of Micrococcus pyogenes var. aureus (strain Duncan). The barrier encloses a volume of $1.66 \pm 0.07 \mathrm{ml}$./g. dry-wt. cells, within which the inorganic phosphate of the cell is confined at a concentration of $c .0 .1 \mathrm{M}$. The inorganic phosphate of the internal and external media exhibit a rapid reciprocal exchange, sensitive to traces of heavy metals. The existence of the osmotic barrier and the characteristics of the phosphate exchange are not in accord with an exchangeadsorption hypothesis; they are in accord with an exchange-diffusion hypothesis, according to which phosphate is shuttled across the osmotic barrier by carrier molecules. There is no experimental justification for supposing the acid-soluble inorganic phosphate of $M$. pyogenes to exist as an acid-labile compound.
\end{abstract}

Considerable amounts of inorganic orthophosphate can be extracted from most bacteria and tissue cells with cold trichloroacetic acid; but it has not been established whether this inorganic phosphate is normally in the free state and held within the cells by an acid-sensitive osmotic barrier, or whether it is held in an acid-labile compound forming part of the cell framework. Attention has been directed towards the latter view by Green and his collaborators (e.g. Green, Atchley, Nordman \& Tepley, 1949) working on the 'gel phosphate' of the cyclophorase system of mammalian tissues, by Harman (1950) working on mammalian heart muscle mitochondria, by Spiegelman's group (Kamen \& Spiegelman, 1948) working on baker's yeast and by Roberts \& Roberts (1950) working on Bacterium coli. According to Roberts \& Wolfe (1952), Bact. coli is permeable, not only to inorganic phosphate ions, but even to sugar phosphates. It is therefore necessary to postulate that the acid-soluble inorganic phosphate of Bact. coli normally exists as an acid-labile compound which cannot diffuse from the cells.

In resting suspensions of Micrococcus pyogenes Mitchell \& Moyle (1953) found, as in Bact. coli (Roberts \& Roberts, 1950), that a reciprocal exchange occurs between the acid-soluble inorganic phosphate of the cells and the inorganic phosphate of the suspension medium. This exchange might be attributed either to exchange-adsorption, as proposed by Roberts \& Roberts (1950) or to a type of mechanism first suggested by Lundegårdh (1945) and later described more exactly and named exchange-diffusion by Ussing (1947). The work described in the present paper was designed to eliminate one or other of the exchange hypotheses in the case of Micrococcus pyogenes var. aureus (strain Duncan). We shall formulate the hypotheses as follows.

Exchange-adsorption hypothesis. The acid-soluble inorganic phosphate is normally held in the cells as a labile compound, freely accessible to the inorganic 
phosphate of the medium. The degree of dissociation of the compound into free phosphate and combining group is very small so that the total amount of bound (acid-soluble) phosphate is practically independent of the concentration of inorganic phosphate in the medium. The reaction between the free phosphate and combining group is reversible, so that a reciprocal exchange of 'inorganic phosphate' between the cells and medium may occur.

Exchange-diffusion hypothesis. The acid-soluble inorganic phosphate exists in the cells as inorganic phosphate, separated from the inorganic phosphate of the medium by an osmotic barrier which is impermeable to phosphate ions but contains carrier groups. The carrier groups cannot leave the barrier, but, owing to thermal agitation, alternately come into contact with the solution on either side, where exchanges may occur between the carrier-phosphate groups and free phosphate ions. For every phosphate group which passes one way across the barrier on a carrier group, the same or another phosphate group must pass the other way when the carrier group returns.

Two kinds of experimental approach towards a decision between the exchange hypotheses suggest themselves.

Permeability measurement. The part of the volume of a cell suspension not accessible to externally added phosphate should be equal to the effective volume of the cells bounded by the hypothetical osmotic barrier. If such a barrier were to exist near the external surface of $M$. pyogenes, the effective cell volume should be approximately equal to the volume of a close-packed centrifuged pad less $26 \%$, the interspace volume for close-packed spheres (Conway \& Downey, 1950). On the other hand, if there were no osmotic barrier, or if the barrier were broken, the effective cell volume should be approximately equal to the apparent specific volume of the major components of the cell, of the order of $0.8 \mathrm{ml}$./g. dry-wt. cells.

Inhibition of exchange. If the exchange-adsorption hypothesis were correct, the acid-soluble inorganic phosphate of the cell would be held by a fixed number of combining groups corresponding in number to the acid-soluble inorganic phosphate molecules. The inhibition of the exchange of the phosphate on a combining group would not be expected to occur unless the inhibitor molecule were close to the combining group. Hence, unless action at a distance were postulated, the number of molecules of a low molecular weight inhibitor required to retard the exchange reaction would have to be of the same order as the number of molecules of acid-soluble inorganic phosphate. If, on the other hand, the exchange-diffusion hypothesis were correct, the exchange reaction would be mediated by a relatively small number of carrier groups in the osmotic barrier. In this case, an inhibitor might retard the exchange reaction when the number of molecules present was similar to the number of carrier groups and therefore small in comparison to the number of molecules of acid-soluble inorganic phosphate.

It was clear at the outset of this work that permeability measurement, by showing the presence or absence of an osmotic barrier for phosphate, would show whether the final system for regulation of exchange was of the exchangeadsorption or of the exchange-diffusion type. The inhibitor studies, however, 
involved a considerable risk; for, although they might disprove the exchangeadsorption hypothesis (depending upon the chance of finding a sufficiently potent inhibitor for the exchange-diffusion system), they would not give positive evidence in favour of exchange-adsorption. Permeability measurements were therefore made first, and when these indicated the occurrence of exchange-diffusion it was considered worth while to begin the inhibitor studies.

\section{METHODS}

Growth and preparation of organism. Cultures of $\boldsymbol{M}$. pyogenes were grown as previously described (Mitchell \& Moyle, 1953). The cells were harvested at a concentration equivalent to $2.5 \mathrm{mg}$. dry-wt./ml., washed three times in distilled water and suspended at a concentration equivalent to $c .200 \mathrm{mg}$. dry-wt./ml. for the permeability measurements and c. $100 \mathrm{mg} . / \mathrm{ml}$. for the exchange measurements. The $\mathrm{pH}$ of the suspensions, measured with a glass electrode, was $c .5 .5$ after washing: it was adjusted to the appropriate value with dilute $\mathrm{HCl}$ or $\mathrm{NaOH}$ immediately before each experiment, the degree of dilution being recorded to correct the dry-weight concentration. The suspensions, stored at $2^{\circ}$, maintained their phosphate-exchanging activity for up to $48 \mathrm{hr}$. After this, the cells deteriorated rapidly and much of their acidsoluble inorganic phosphate escaped. In the present work, suspensions not more than $12 \mathrm{hr}$. old were used.

Estimation of $\mathbf{P}$ and ${ }^{32} \mathbf{P}$. The methods used were as previously described (Mitchell \& Moyle, 1953).

Estimation of dry-weight. The approximate concentrations of the washed cell suspensions in distilled water were adjusted turbidimetrically. The exact dry-weight concentrations were subsequently measured by drying samples containing c. $200 \mathrm{mg}$. to constant weight at $105^{\circ}$ and weighing to $0.5 \mathrm{mg}$. The suspension densities subsequently described in $\mathrm{mg}$./ml. refer to $\mathrm{mg}$. dry-wt. cells/ml.

\section{Permeability measurements}

Normal cells. It was advisable to determine the external phosphate space in the presence of a relatively large concentration of salt to minimize the adsorption of phosphate on the cell surfaces and to control the osmotic and ionic condition of the medium. Sodium chloride and phosphate were therefore added in amounts which would give final concentrations in the external water space of about $100 \mathrm{~mm}$ and $5 \mathrm{~mm}$, respectively. Preliminary experiments showed that in the concentrated cell suspension containing $c .200 \mathrm{mg} . / \mathrm{ml}$, the water space accessible to externally added phosphate was $c .0 .5 \mathrm{ml} . / \mathrm{ml}$. suspension. Two ml. samples of the concentrated suspension, adjusted to $\mathrm{pH} 7$ were pipetted into test-tubes $7 \mathrm{~cm}$. in length, of total capacity $2.5 \mathrm{ml}$. To this suspension, $0.1 \mathrm{ml}$. $\mathrm{M}-\mathrm{NaCl}$ alone (control) or containing $0.025 \mathrm{M}-\mathrm{Na}_{2} \mathrm{HPO}_{4} \mp$ $0.025 \mathrm{M}-\mathrm{NaH}_{2} \mathrm{PO}_{4}$ (test) was added. The suspensions were rapidly mixed with a fine glass rod and centrifuged at $3000 \mathrm{~g}$ for $1 \mathrm{hr}$. at $2^{\circ}$, either immediately or after standing at $25^{\circ}$ for $30 \mathrm{~min}$. The concentrations of phosphate were estimated in duplicate $0.1 \mathrm{ml}$. samples of the supernatants and called [control P] 
and [test P]. To compensate for systematic volumetric errors, $0 \cdot 1 \mathrm{ml}$. of the $\mathrm{M}-\mathrm{NaCl}$ containing $0.05 \mathrm{M}$-phosphate was pipetted into $1 \mathrm{ml}$. distilled water and the phosphate concentration was estimated in $0.1 \mathrm{ml}$. samples of this dilution exactly as for the supernatants and called [standard P]. The effective cell volume ( $V \mathrm{ml}$.) was calculated from the equation:

$$
\frac{[\text { standard } \mathbf{P}]}{[\text { test } \mathbf{P}]-[\text { control } \mathbf{P}]}=\frac{2 \cdot 1-V}{1 \cdot 1} \text {. }
$$

The total supernatant volumes were estimated in graduated pipettes, and the volumes of the centrifuged cell pads were obtained by difference. Pipettes with extremely fine tips were used so that the supernatant liquid could be quantitatively drawn into them with a thick-walled rubber teat.

Damaged cells. The acid-soluble inorganic phosphate is liberated from suspensions of $\boldsymbol{M}$. pyogenes within $20 \mathrm{~min}$. by $5 \%$ trichloroacetic acid at $2^{\circ}$. The experiment described in Fig. 1 showed that the acid-soluble inorganic

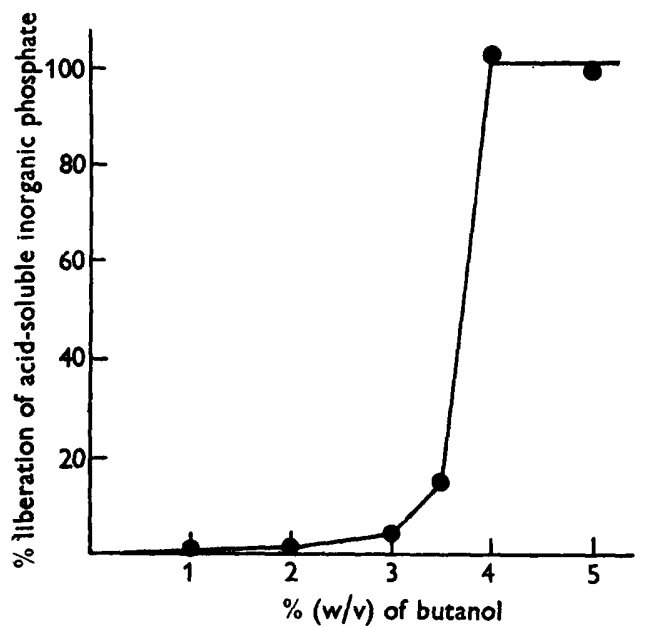

Fig. 1. The percentage of the acid-soluble inorganic phosphate of a $20 \mathrm{mg} . / \mathrm{ml}$. cell suspension liberated by $n$-butanol in $20 \mathrm{~min}$. at $15^{\circ}$ at $\mathrm{pH} 7$.

phosphate is also quantitatively liberated within $20 \mathrm{~min}$. at $15^{\circ}$ and at $\mathrm{pH} 7$ by concentrations of $n$-butanol exceeding $4 \%(\mathrm{w} / \mathrm{v})$. The external phosphate space and effective cell volume in suspensions of cells damaged by trichloroacetic acid or butanol were determined as follows. Two ml. samples of the concentrated suspension of normal cells were pipetted into test-tubes $10 \mathrm{~cm}$. in length of total capacity $6 \mathrm{ml}$. The suspensions were centrifuged at $3000 \mathrm{~g}$ for $1 \mathrm{hr}$. and $0.5 \mathrm{ml}$. of the supernatants was discarded. Butanol $(0.1 \mathrm{ml}$.) or trichloroacetic acid $(0 \cdot 15 \mathrm{ml}$. of a $50 \%(\mathrm{w} / \mathrm{v})$ solution) was now added to pairs of tubes and stirred rapidly into the pads of cells with a fine glass rod. After $20 \mathrm{~min}$, , one of each pair was appropriately diluted with $3 \mathrm{ml}$. of $5 \%$ $(w / v)$ butanol or trichloroacetic acid, and the undiluted and diluted suspensions were centrifuged at $3000 \mathrm{~g}$ for $1 \mathrm{hr}$. The volumes of the supernatants from the 
undiluted suspensions were measured so that the contraction of the cell pads on treatment with butanol or trichloroacetic acid could be obtained by difference. The concentration of phosphate was estimated in the supernatants from the undiluted ([undil. P]) and diluted ([dil. P]) suspensions, using $0.2 \mathrm{ml}$. samples, suitably diluted. The effective volumes of the cells in trichloroacetic acid $\left(v_{A} \mathrm{ml}.\right)$ and in butanol $\left(v_{B} \mathrm{ml}\right.$.) were calculated from the equations:

$$
\begin{aligned}
& \frac{\text { [undil. P] }}{[\text { dil. P] }}=\frac{4 \cdot 65-v_{A}}{1 \cdot 65-v_{A}} \text { for trichloroacetic acid. } \\
& \frac{\text { [undil. P }]}{\text { [dil. P] }}=\frac{4 \cdot 60-v_{B}}{1 \cdot 60-v_{B}} \text { for butanol. }
\end{aligned}
$$

Previous experience indicated that the standard deviation of the phosphate and volumetric measurements was $c . \pm 1 \%$. The values of $V$ and $v$ are given by differences between experimentally measured values about twice and five times as large, respectively. It was anticipated, therefore, that it should be possible to measure $V$ to within about $\pm 2 \%$ and $v$ to within about $\pm 5 \%$.

\section{Exchange measurements}

The rate of exchange of inorganic phosphate across the cell surface can be determined by labelling the phosphate of the medium or of the cells with ${ }^{32} \mathbf{P}$ and subsequently observing the rate of mixing of ${ }^{31} \mathrm{P}$ and ${ }^{32} \mathrm{P}$.

Theoretical. Assuming the system regulating the exchange of inorganic phosphate to be of the exchange-diffusion type, a simple relationship can be shown to exist between the effective rate of shuttling $(\dot{\mathbf{P}})$ of phosphate by the carrier compound in the osmotic barrier, the total amounts of inorganic phosphate in the internal $\left(P_{I}\right)$ and external $\left(P_{E}\right)$ media and the rate of change of the relative specific activity of the phosphate on either side of the barrier. We shall suppose that the probability of carriage across the barrier of a molecule of phosphate containing ${ }^{32} \mathrm{P}$ is the same as the proportion of the total number of inorganic phosphate molecules which contain ${ }^{32} \mathrm{P}$, namely ${ }^{32} \mathbf{P} / \mathbf{P}$, on the side of the barrier from which the phosphate is being carried. Hence, the net rate of transfer of ${ }^{32} \mathrm{P}$ into the cells may be written

$$
\frac{d{ }^{32} \mathbf{P}_{\mathrm{I}}}{d t}=\dot{\mathbf{P}}\left(\frac{{ }^{32} \mathbf{P}_{\mathrm{B}}}{\mathbf{P}_{\mathrm{E}}}-\frac{{ }^{32} \mathbf{P}_{\mathrm{I}}}{\mathbf{P}_{\mathrm{I}}}\right)
$$

In the present experiments, it will be shown that the amounts of total inorganic phosphate and phosphate containing ${ }^{32} \mathrm{P}$ were constant so that

$$
\mathbf{P}_{\mathrm{I}}+\mathbf{P}_{\mathrm{E}}=k\left({ }^{32} \mathbf{P}_{\mathrm{I}}+{ }^{32} \mathbf{P}_{\mathrm{E}}\right), \quad k \text { being a constant. }
$$

The relative specific activity $R$, is defined by

$$
\boldsymbol{R}=k .{ }^{32} \mathbf{P} / \mathbf{P} \text {. }
$$

Eliminating either ${ }^{32} P_{E}$ or ${ }^{32} P_{I}$ and assuming $P_{E}$ and $P_{I}$ to be constants, equation 4 can be integrated from time $t_{1}$ to $t_{2}$, giving

$$
\dot{\mathbf{P}}=\frac{1}{t_{2}-t_{1}} \cdot \frac{\mathbf{P}_{\mathrm{E}} \cdot \mathbf{P}_{\mathrm{I}}}{\mathbf{P}_{\mathrm{E}}+\mathbf{P}_{\mathrm{I}}} \ln \left(\frac{1-R_{t_{1}}}{1-R_{t_{s}}}\right)_{\mathrm{I} \text { or } \mathrm{E}} .
$$


The $R$ values at times $t_{1}$ and $t_{2}$ inside the natural logarithm (ln) of equation (7) both refer either to the internal or to the external medium. It was convenient to express $t$ in minutes and $\mathbf{P}$ in $\mu$ mole/g. cell dry-weight ( $\mu$ mole/g.). The units of $\dot{\mathbf{P}}$ are therefore $\mu \mathrm{mole} / \mathrm{g} . / \mathrm{min}$.

It should be understood that equation (7) describes the strictly reciprocal exchange of a component between two systems in which the amount of the component remains constant: it is independent of the nature of the exchange mechanism. Similar equations have been used extensively in the past, the most recent derivation being by Krebs, Eggleston \& Terner (1951) who refer to the earlier literature.

Experimental. In most experiments, the external medium was marked with ${ }^{32} \mathrm{P}$ and the decrease in $\boldsymbol{R}_{\mathrm{m}}$ and the increase in $\boldsymbol{R}_{\mathrm{I}}$ were determined during a time interval measured from the moment of adding the ${ }^{32} \mathrm{P}$. It was technically most convenient to determine the ${ }^{32} \mathbf{P}$ content of the cells (from which the $\boldsymbol{R}_{\mathrm{I}}$ value was obtained) in the presence of a considerable proportion of the phosphate of the medium. It was therefore necessary to work with external concentrations of phosphate low enough to make $P_{I}$ of comparable magnitude to $P_{\mathrm{E}}$ in cell suspensions of reasonably low concentration. In such suspensions, measurements could be made equally well when the inorganic phosphate of the cells was initially marked with ${ }^{32} P$ and the value of $R_{\mathrm{E}}$ was determined. The technique described below was found to give satisfactory results.

Basic technique. Into test tubes $10 \mathrm{~cm}$. long and total capacity $6 \mathrm{ml}$,, standard solutions were measured to give final concentrations (in $5 \mathrm{ml}$.) of $0 \cdot 1 \mathrm{~m}-\mathrm{NaCl}$ and $2 \mathrm{~mm}$-sodium phosphates containing $1 \mu \mathrm{C}$. of ${ }^{32} \mathrm{P} / \mathrm{ml}$. Solutions of substances expected to inhibit or stimulate phosphate exchange were added to give the required final concentration, and dilute $\mathrm{HCl}$ or $\mathrm{NaOH}$ were added to give the required final $\mathrm{pH}$ value, measured in duplicate samples with a glass electrode. The volume was made up to $4 \mathrm{ml}$. with distilled water. After temperature equilibration at $15^{\circ}$ or $25^{\circ}, 1 \mathrm{ml}$. of washed cell suspension (c. $100 \mathrm{mg} . / \mathrm{ml}$.) was rapidly mixed with $4 \mathrm{ml}$. of the medium and the resulting suspension was kept at constant temperature for a measured time. It was then centrifuged at $3000 \mathrm{~g}$ for $10 \mathrm{~min}$. and $3 \mathrm{ml}$. of the supernatant medium were withdrawn. Three ml. of distilled water were added to the remaining $2 \mathrm{ml}$, and the cells redispersed. Duplicate $0.1 \mathrm{ml}$. samples of the supernatant medium and redispersed suspension were taken to estimate the concentrations of ${ }^{32} \mathrm{P}$ ( $M$ and $N$ counts $/ \mathrm{ml}$. respectively), and duplicate $0.2 \mathrm{ml}$. samples of the supernatant medium were taken to estimate $\mathbf{P}(r \mu \mathrm{mole} / \mathrm{ml}$. $)$. The total amounts of ${ }^{32} \mathrm{P}$ and $\mathbf{P}$ were calculated as counts or $\mu$ mole in $Z \mathrm{ml}$. (c. $50 \mathrm{ml}$.) of the suspension at the concentration of $c .20 \mathrm{mg} . / \mathrm{ml}$., representing counts or $\mu \mathrm{mole} / \mathrm{g}$. cells. For each batch of cells the value of $\boldsymbol{Z}$ was determined gravimetrically. The external phosphate space in the suspension was $0.95 \mathrm{ml} . / \mathrm{ml}$. (see below). Hence, ${ }^{32} \mathrm{P}_{\mathrm{H}}=M . Z / 0 \cdot 95$ and $\mathrm{P}_{\mathrm{B}}=r . Z / 0 \cdot 95$. After withdrawing $3 \mathrm{ml}$. of the medium from $5 \mathrm{ml}$. of centrifuged suspension, only $1.75 \mathrm{ml}$. of the external phosphate space remained, and this was diluted to $4.75 \mathrm{ml}$. when the suspension was redispersed. Hence, ${ }^{32} P_{I}=Z \cdot\left(N-{ }^{32} P_{E} \cdot 1 \cdot 75 / 4 \cdot 75\right)$. 
To measure the inorganic $\mathbf{P}$ content of the cells, $1 \mathrm{ml}$. of the washed cell suspension was added to each of two tubes, one containing $4 \mathrm{ml}$. distilled water (blank) and the other $4 \mathrm{ml}$. of $6.25 \%(\mathrm{w} / \mathrm{v})$ trichloroacetic acid. After $20 \mathrm{~min}$. at $2^{\circ}$, the suspensions were centrifuged, and duplicate $0.2 \mathrm{ml}$. samples were taken to estimate the concentration of phosphate in the blank supernatant ( $b \mu \mathrm{mole} / \mathrm{ml}$.) and in the trichloroacetic acid extract ( $a \mu \mathrm{mole} / \mathrm{ml}$.). The external phosphate space was $0.98 \mathrm{ml} . / \mathrm{ml}$. in the trichloroacetic acidtreated suspension (see below). Hence, $P_{1}=Z \cdot(a-b) / 0 \cdot 98$. In the present work, $b$ never exceeded $5 \%$ of $a$.

Having obtained $\mathbf{P}_{\mathrm{R}}, \mathbf{P}_{\mathrm{I}},{ }^{32} \mathbf{P}_{\mathrm{R}}$ and ${ }^{32} \mathbf{P}_{\mathrm{I}}$, the values of $\boldsymbol{R}_{\mathrm{R}}$ and $\boldsymbol{R}_{\mathrm{I}}$ could be found, using equations (5) and (6). For any single experiment, $R_{\mathrm{E}}$ and $\boldsymbol{R}_{\mathrm{I}}$ are not, of course, independent variables, and substitution of either $R_{\mathrm{z}}$ or $\boldsymbol{R}_{\mathrm{I}}$ into equation (7) will give the same value for $P$. In practice, however, several suspensions were handled together so that mean values for ${ }^{{ }^{22}} \mathbf{P}_{\mathrm{I}}+{ }^{32} \mathbf{P}_{I}$ and $\mathbf{P}_{\mathrm{I}}+\mathbf{P}_{\mathrm{I}}$ could be obtained. These values were occasionally used to calculate $\boldsymbol{R}_{\mathrm{B}}$ or $\boldsymbol{R}_{\mathrm{I}}$ independently in a group of experiments where a $\mathbf{P}$ value was obviously false or was lost by an accident. But, in general, the mean values were employed only as a check on the reliability of individual measurements.

Separation of organic and inorganic components of $\mathrm{P}_{\mathrm{I}}$. In order to find the proportions of the phosphate entering the organic and inorganic acid-soluble fractions during exchange, the basic technique was varied in the following way. At the end of the time allowed for exchange, the $5 \mathrm{ml}$. of suspension were centrifuged, and $3 \mathrm{ml}$. of the medium were withdrawn as before. The cells were redispersed in the remaining $2 \mathrm{ml}$. and $0.4 \mathrm{ml}$. of $30 \%(\mathrm{w} / \mathrm{v})$ trichloroacetic acid was added. The suspension was centrifuged after 20 min. at $2^{\circ}$, and the total $\mathbf{P}$, inorganic $\mathbf{P}$ and ${ }^{32} \mathbf{P}$ contents of the supernatant were determined using $0.1 \mathrm{ml}$. samples. To $1 \mathrm{ml}$. of the supernatant, $0.05 \mathrm{ml} .20 \mathrm{~N}$-ammonium hydroxide and $0.05 \mathrm{ml}$. magnesia mixture were added, and the inorganic phosphate was allowed to precipitate at $2^{\circ}$ overnight. The precipitate was centrifuged and $0 \cdot 1 \mathrm{ml}$. samples of the supernatant were taken for estimation of the organic $\mathbf{P}$ and organic ${ }^{32} \mathbf{P}$ contents. The mutual contamination of the organic and inorganic $P$ separated by this method was not greater than $3 \%$. The values of $\mathbf{P}_{\mathrm{x}}, \mathbf{P}_{\mathrm{I}},{ }^{32} \mathbf{P}_{\mathrm{E}}$ and ${ }^{32} \mathbf{P}_{\mathrm{I}}$ were calculated by applying principles similar to those of the basic technique, the main difference being that $\mathbf{P}_{\mathbf{E}}$ and ${ }^{32} \mathbf{P}_{\mathrm{r}}$ were now divided into inorganic and organic fractions.

Reversal of movement of ${ }^{32} \mathrm{P}$. The technique used for measuring the phosphate exchange by the passage of ${ }^{32} \mathrm{P}$ from cells to medium was essentially the same as the basic technique. It differed in that the cells were first incubated for $30 \mathrm{~min}$. at $25^{\circ}$ in $0 \cdot 1 \mathrm{M}-\mathrm{NaCl}$ at $\mathrm{pH} \mathrm{7}$, at a dry-weight concentration of $20 \mathrm{mg} . / \mathrm{ml}$., with $1 \mu \mathrm{C}$. of ${ }^{32} \mathrm{P}$-marked phosphate $/ \mathrm{ml}$. containing only c. $10^{-5} \mathrm{M}$-carrier phosphate. The cell suspension was centrifuged, washed once in distilled water, and resuspended in distilled water at a concentration of c. $100 \mathrm{mg}$. $/ \mathrm{ml}$. This suspension was used as in the basic technique, the ${ }^{32} \mathbf{P}$ of the medium being omitted. 


\section{RESULTS}

Permeability

Effective cell volumes. The volumes of $M$. pyogenes not penetrable by inorganic phosphate before and after injury by $5 \%$ trichloroacetic acid or butanol are shown in Table 1 . Whereas, before injury, the mean volume was $\mathbf{2 . 4 2} \pm 0.05 \mathrm{ml}$./g., after injury it decreased to $0.76 \pm 0.07 \mathrm{ml}$. $/ \mathrm{g}$. There must therefore be an internal space in intact cells which is not accessible to externally added phosphate. It was conceivable that this internal space might normally be inaccessible to free phosphate ions because of electrostatic repulsion by negative groups within a gel structure, and that trichloroacetic acid might make the space available by discharging the gel. This cannot, however, be the case because butanol at $\mathrm{pH} 7$ was as effective as trichloroacetic acid in allowing penetration of inorganic phosphate.

Table 1. Effective phosphate-impenetrable volumes of centrifuged cells of Micrococcus pyogenes

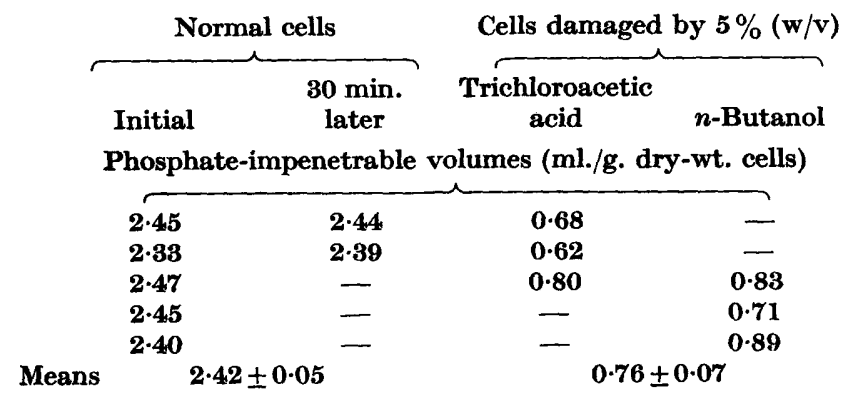

When the cells were damaged by trichloroacetic acid or butanol, practically none of the protein or nucleic acid escaped, but $18 \%$ of the dry weight was lost as soluble components of relatively small molecular weight, which could readily pass through cellophan dialysis tubing. The effective volume of the cell material which centrifuged down after damage was therefore $0.76 \pm 0.07 \mathrm{ml} . / 0.82 \mathrm{~g} .=0.93 \pm 0.09 \mathrm{ml} . / \mathrm{g}$. This value is within the range expected for the apparent specific volume of the cell components.

The volumes of the close-packed pads of cells are shown in Table 2 . The volume of the cell pad decreased by $26 \cdot 9 \pm 1 \cdot 4 \%$ after damage by trichloro-

Table 2. Close-packed cell pad volumes

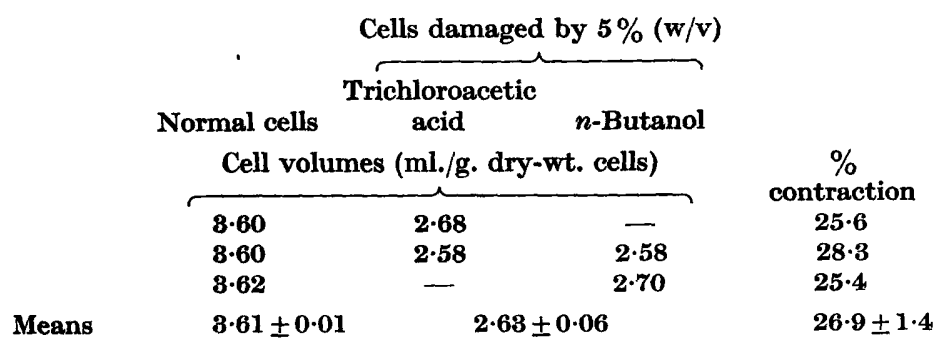


acetic acid or butanol. This agrees well with the figure of $26 \%$ calculated by Conway \& Downey (1950) for the interspace volume for close-packed spheres. The inference is that when the osmotic barrier is damaged, the cells lose their internal turgor pressure and are then capable of distortion into dodecahedra with zero interspace. If the external surfaces of the osmotic barriers were to make contact, the volume of the close-packed damaged cells $(2 \cdot 63 \pm 0 \cdot 06 \mathrm{ml}$. $)$ should be equal to the phosphate impenetrable volume $(2.42 \pm 0.05 \mathrm{ml}$.). The difference $0.21 \pm 0.06 \mathrm{ml}$. (c. $9 \%$ of the cell volume) represents the amount of water lying between the osmotic barriers of the cells. The cells are about $0.7 \mu$. in diameter at the time of harvesting (Mitchell \& Moyle, 1951), and the water lying between them must therefore be equivalent to a layer only c. $20 \mathrm{~m} \mu$. thick. This water may simply be trapped between the cells, the viscous resistance preventing its escape during the one-hour period of centrifuging. However, other electrical or mechanical forces may also resist the closer approach of the osmotic barriers of the cells. There may, for instance, be a porous layer situated externally to the osmotic barrier. At all events, the behaviour of the suspensions of $M$. pyogenes in these experiments is in accord with the view that an osmotic barrier for inorganic phosphate exists near the external surface of the cells, and that this barrier envelops an internal space of $(2.42-0.76) \pm 0.07=1.66 \pm 0.07 \mathrm{ml} . / \mathrm{g}$., within which the acid-soluble inorganic phosphate is confined.

\section{Phosphate exchange}

Application of equation (7). In the system represented by equation (7), $\mathbf{P}_{\mathbf{E}}$ and $\mathbf{P}_{\mathbf{I}}$ are the total amounts of inorganic phosphate between which exchange occurs. These amounts, and also the total ${ }^{32} \mathrm{P}$ content of the system are considered to be constant. In other words, equation (7) is only applicable to the exchange experiments as long as a negligibly small proportion of the s2P enters the organic fractions of the cells, and $P_{E}$ and $P_{I}$ remain constant. It was previously found (Mitchell \& Moyle, 1953), that under highly aerobic conditions, c. $90 \%$ of the ${ }^{82} \mathrm{P}$ which entered resting cells at $25^{\circ}$ in $90 \mathrm{~min}$. was present in the acid-soluble inorganic fraction. About $1 \%$ of the ${ }^{32} \mathrm{P}$ entered the lipid and $10 \%$ entered the acid-soluble organic fraction. The present experiments were carried out under comparatively anaerobic conditions in narrow test tubes, with the aim of minimizing the residual metabolism and the entry of ${ }^{32} \mathbf{P}$ into the organic fractions.

The percentages of the total ${ }^{32} \mathrm{P}$ entering the inorganic and organic acidsoluble fractions, measured during phosphate exchange at $25^{\circ}$ at $\mathrm{pH} 7$ are shown in Table 3, together with the values of $\mathbf{P}_{I I}$ and $\mathbf{P}_{I}$. The acid-soluble organic faction was contaminated by a maximum of $3 \%$ of the inorganic fraction, and upper and lower figures for the ${ }^{32} \mathrm{P}$ content of the organic fraction are accordingly given in Table 3 . There was very little change in the values of $P_{B}$ and $P_{I}$, and even after $2 \mathrm{hr} .96 \%$ of the ${ }^{32} \mathrm{P}$ was still present in the inorganic acid-soluble fraction. The experimental values were therefore considered properly to represent $P_{\mathrm{II}}, \mathbf{P}_{\mathrm{I}},{ }^{32} \mathrm{P}_{\mathrm{R}}$ and ${ }^{32} \mathrm{P}_{\mathrm{I}}$ in the system described by equation 7 . 
Table 3. The values of $\mathbf{P}_{\mathbf{x}}$ and $\mathrm{P}_{\mathrm{I}}$ and entry of ${ }^{32} \mathrm{P}$ into the organic fractions during phosphate exchange at $25^{\circ}$ at $\mathrm{pH} 7$

\begin{tabular}{|c|c|c|c|c|}
\hline \multirow{2}{*}{$\begin{array}{l}\text { Time } \\
\text { (min.) }\end{array}$} & \multicolumn{2}{|c|}{$\begin{array}{c}\text { Percentages of total }{ }^{32} \mathrm{P} \\
\text { in the acid-soluble } \\
\text { fractions }\end{array}$} & \multirow{2}{*}{$\underset{(\mu \mathrm{mol} . / \mathrm{g} .)}{\mathbf{P}_{\mathbf{E}}}$} & \multirow{2}{*}{$\underset{(\mu \mathrm{mol} . / \mathrm{g} .)}{\mathbf{P}_{\mathbf{I}}}$} \\
\hline & Inorganic & Organic & & \\
\hline 25 & 98 & $1 \cdot \mathbf{2}-\mathbf{3} \cdot 0$ & 105 & 142 \\
\hline 45 & 97 & $2 \cdot 3-3 \cdot 7$ & 104 & 144 \\
\hline 90 & 98 & $3 \cdot 1-4 \cdot 3$ & 104 & 142 \\
\hline 150 & 96 & $3 \cdot 7-4 \cdot 8$ & 107 & 145 \\
\hline
\end{tabular}

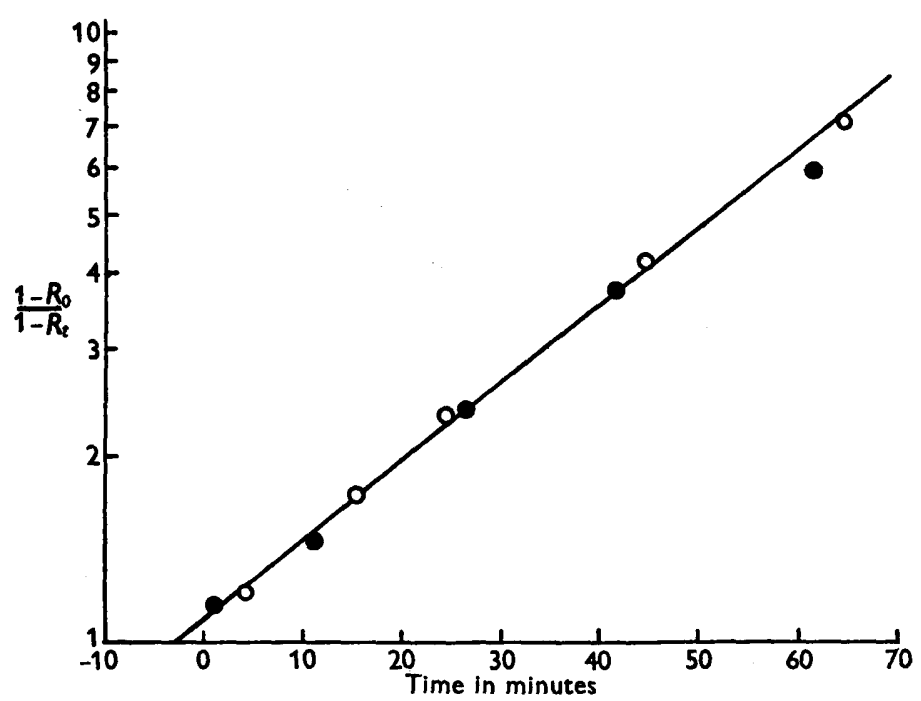

Fig. 2. Verification of equation (7). The plot of $\log \left(1-R_{0}\right) /\left(1-R_{t}\right)$ against $t$; the ${ }^{32} \mathrm{P}$ moving into the cells, - - ; the ${ }^{32} \mathrm{P}$ moving out of the cells, $-\mathrm{O}-\mathrm{O}-$. At $\mathrm{pH} 7$ and $25^{\circ}$.

It was now necessary to verify the relationship between $\dot{\mathrm{P}}, t$ and $R$ described by equation ( 7$)$. The time course of the changes in $R$ during phosphate exchange at $25^{\circ}$ at $\mathrm{pH} 7$, with an external phosphate concentration of $2 \mathrm{~mm}$, was observed with the ${ }^{32} \mathbf{P}$ moving from the medium to the cells and in the reverse direction. Fig. 2 shows the plots of $\log \left(1-R_{0}\right) /\left(1-R_{t}\right)$ against $t$, the time being measured from the moment of mixing the washed suspension with the medium to the moment of starting the centrifuge. The points in this and in five other similar experiments (two of them at $15^{\circ}$ ) fell on straight lines, the slope of which was independent of the direction of movement of the ${ }^{32} \mathrm{P}$, within experimental error. The intercept of the lines on the time axis $(-3 \mathrm{~min}$.) represents the effective time for which exchange continued during centrifuging. It was evident that the course of the phosphate exchange was described by equation (7), and that values of $\dot{\mathbf{P}}$ could be estimated within a few per cent from a single determination of $R$ after a known lapse of time $t+3 \mathrm{~min}$. The values of $\dot{\mathrm{P}}$ at $25^{\circ}$ at $\mathrm{pH} 7$ varied between 3 and $6 \mu \mathrm{mole} / \mathrm{g} . / \mathrm{min}$. in different batches of cells. However, in a given batch of 
washed suspension, measurements of $\dot{\mathrm{P}}$ were reproducible to within $\pm 5 \%$, allowing a value of $15 \mathrm{~min}$. for $t$.

The $\mathrm{pH}$ value, temperature and ionic composition for $\dot{\mathbf{P}}$ measurements. The dependence of $\dot{\mathbf{P}}$ on $\mathbf{p H}$, determined under the conditions described above, is shown in Fig. 3. The pH values plotted are the means of the values measured in duplicate suspensions at the beginning and end of the period of phosphate exchange. It was noted that a downward drift of $\mathrm{pH}$ occurred at the rate of c. $0 \cdot 1$ unit/hr.

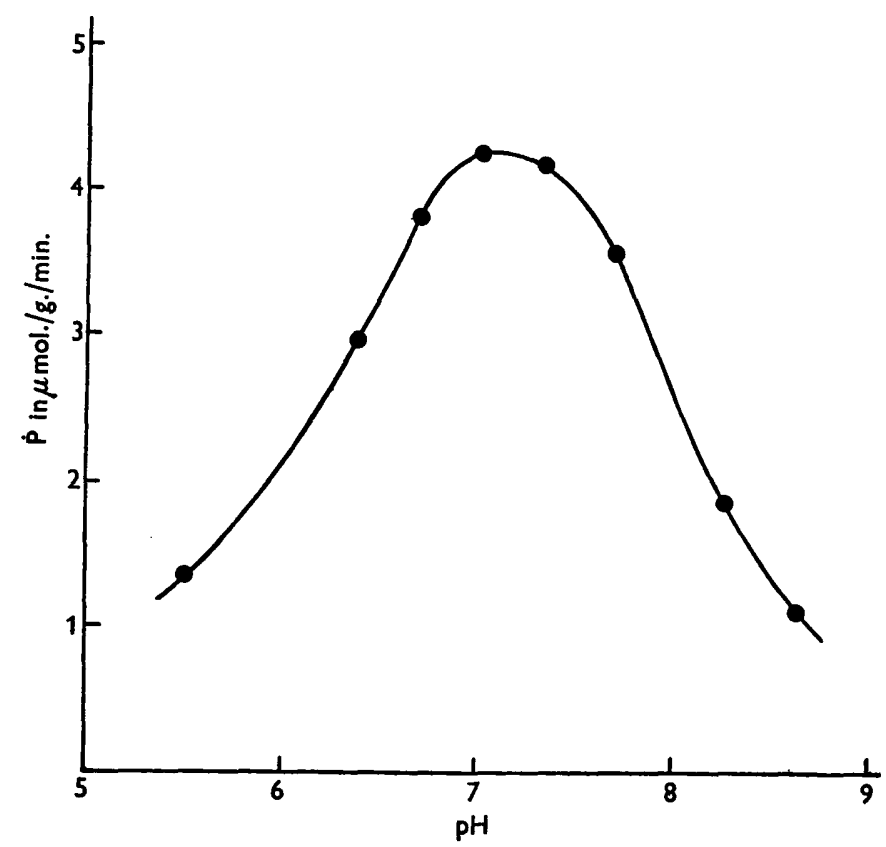

Fig. 3. The dependence of the rate of exchange of phosphate $(\dot{\mathrm{P}})$ on $\mathrm{pH}$ in $0.1 \mathrm{M}-\mathrm{NaCl}$ and $2 \mathrm{~mm}-$ phosphate at $25^{\circ}$.

In order to make it easier to handle several tubes of suspension at a time in the inhibition studies, and to reduce errors of timing, exchange measurements were made at $15^{\circ}$. The value of $\dot{\mathbf{P}}$ varied between 0.6 and $1.2 \mu \mathrm{mole} / \mathrm{g}$./ min. in different batches of cells, but in a given batch the measurements were reproducible to within $\pm 5 \%$ allowing a value of $60 \mathrm{~min}$. for $t$.

In previous work (Mitchell \& Moyle, 1953) $\mathrm{K}^{+}$and $\mathrm{Mg}^{++}$were present in the medium during phosphate exchange. It was found, however, that the addition of either $10 \mathrm{~mm}-\mathrm{KCl}$ or $3 \mathrm{~mm}-\mathrm{MgCl}_{2}$, or of both simultaneously, to the saline used in the present experiments did not affect $\dot{\mathbf{P}}$ significantly.

Inhibition of phosphate exchange. All the inhibition measurements were carried out at $\mathrm{pH} 7$ at $15^{\circ}$ in the presence of $0 \cdot 1 \mathrm{M}-\mathrm{NaCl}$ and $2 \mathrm{~mm}$-phosphate. About 100 'inhibitors' were tested, the majority of which had no effect or were effective only at relatively high concentrations. The less effective inhibitors provided information about the nature of the exchange system 
which it will be appropriate to consider in a later paper. Only the more potent group, the heavy metal cations, were of value in deciding between the exchange-adsorption and exchange-diffusion hypotheses. The percentage depression of $\dot{\mathbf{P}}$ by cations added as chlorides to give an initial concentration of $10^{-4} \mathrm{M}$ in a cell suspension of $20.3 \mathrm{mg} . / \mathrm{ml}$. was as shown in the following brackets : Phenyl-Hg ${ }^{+}(72), \mathrm{Hg}^{++}(48), \mathrm{Ag}^{+}(38), \mathrm{Cu}^{++}(32), \mathrm{Cd}^{++}(21), \mathrm{Co}^{++}$

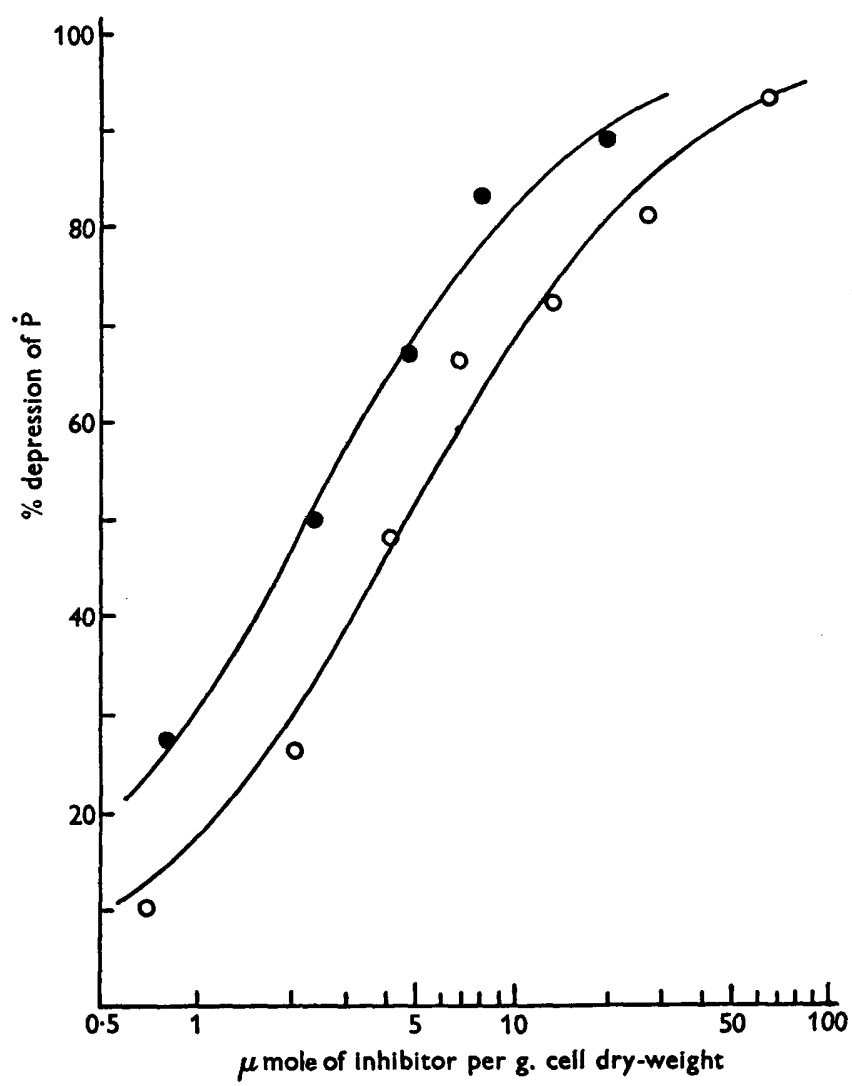

Fig. 4. The dependence of the rate of exchange of phosphate $(\dot{\mathbf{P}})$ on the number of $\mu$ mole of inhibitor present/g. cell dry-wt. Cell suspension density $18 \cdot 7 \mathrm{mg} . / \mathrm{ml}$.; external phosphate concentration $2 \mathrm{~mm}$; at $\mathrm{pH} 7$ and $15^{\circ}$. For phenyl- $\mathrm{HgCl}(O)$ and $\mathrm{HgCl}_{2}(\mathrm{O})$. Smooth curves given by $K=M \cdot n /(100-n), M$ being amount of metal and $n$ the percentage depression of $\dot{\mathrm{P}}$; the constant $K$ being $4 \cdot 7 \mu$ mole/g. for $\mathrm{HgCl}_{2}$ and $2 \cdot 2 \mu \mathrm{mole} / \mathrm{g}$. for phenyl-HgCl.

(10), $\mathrm{Zn}^{++}$(32?). The ions $\mathrm{Ca}^{++}, \mathrm{Sr}^{++}, \mathrm{Ba}^{++}, \mathrm{Be}^{++}, \mathrm{Mg}^{++}, \mathrm{Mn}^{++}$, and $\mathrm{Pb}^{++}$ gave no depression. It was possible that, for some of the metals, an apparent effect on $\dot{\mathbf{P}}$ might have been caused by precipitation of the sparingly soluble phosphate from the medium. The routine measurements showed, however, that the values of $P_{m}$ were not affected in these experiments. Zinc, unlike any of the other metals, caused complete flocculation of the cell suspensions. 
Although the zinc-containing suspension was redispersed every few minutes during phosphate exchange, it is probable that the loss of contact between the cells and medium gave an artificially large depression of $\dot{\mathbf{P}}$. The dependence of the degree of depression of $\dot{\mathbf{P}}$ on the amount of the two most potent inhibitors is shown in the semi-logarithmic plot of Fig. 4. The smooth curves represent the relationship $K=M \cdot n /(100-n), M$ being the amount of metal ion, $n$ the percentage depression of $\dot{\mathbf{P}}$, and $K$ a constant. The fact that the points lie close to the smooth curves shows that inhibition is the result of a reaction of the type $M+X \rightarrow M X, X$ representing the sites which, when combined with metal (as $M X$ ), cause inactivation of a corresponding proportion of the units controlling the exchange of phosphate. In the experiments of Fig. 4, the cells contained $147 \mu$ mole acid-soluble inorganic phosphate/g., and the values of $K$ were $4.7 \mu \mathrm{mole} / \mathrm{g}$. for $\mathrm{Hg}^{++}$and $\mathbf{2 \cdot 2} \mu \mathrm{mole} / \mathrm{g}$. for phenyl-Hg ${ }^{+}$. Hence, the values of $X$ per 100 molecules of acid-soluble inorganic phosphate must be 6.4 for $\mathrm{Hg}^{++}$and only 3.0 for phenyl- $\mathrm{Hg}^{+}$.

Evidently, therefore, the number of units controlling the exchange of phosphate is small in comparison to the number of adsorption sites of the exchange-diffusion hypothesis; and unless action at a distance were postulated, the observed inhibition could not be explained on the basis of exchangeadsorption. On the other hand, the results can be explained on the basis of an exchange-diffusion system in which the number of carrier groups which transfer phosphate across the osmotic barrier is not greater than $3 \%$ of the total number of inorganic phosphate molecules present in the internal medium of the cells.

\section{DISCUSSION}

The evidence of the permeability and inhibitor studies is strong enough to warrant rejection of the exchange-adsorption hypothesis as it stands. Moreover, the behaviour of the system controlling the exchange of inorganic phosphate across the cell surface is entirely in accord with the exchangediffusion hypothesis. It is important to realize, however, that we have not investigated what proportion of the inorganic phosphate of the internal medium of the cells exists as free ions. It is implicit in the exchange-diffusion hypothesis that the internal inorganic phosphate shall be free to react with the carrier groups in the osmotic barrier; but this does not necessarily imply that the internal inorganic phosphate must exist as free ions. Under the conditions of the present experiments, $1 \mathrm{~g}$. dry-weight of cells contained c. $150 \mu$ mole inorganic phosphate in an internal space of $1.66 \pm 0.07 \mathrm{ml}$. Hence, the phosphate concentration in the internal medium was c. $0.1 \mathrm{M}$. If this were to exist as the completely dissociated alkali salts at $\mathrm{pH} 7$, the osmotic pressure would be slightly above 5 atmospheres-a considerable pressure for only one of the many solutes which constitute $18 \%$ of the cell dry-weight. As a whole, it will be seen that the internal solutes form about a $10 \%(w / v)$ solution. Discussion of the osmotic pressure exerted by the internal solutes in relation to the stress on the cell envelope should await osmotic measurements which are now in progress in this laboratory. It would be appropriate 
to remark here, however, that for a sphere the size of $M$. pyogenes, $0.7 \mu$. in diameter, an internal pressure of 5 atmospheres corresponds to a stress of 87 dynes/cm., only slightly above the surface tension of water. The cell envelope, being made of a protein similar in composition to silk fibroin (Mitchell \& Moyle, 1951), may be able to withstand tensions much greater than this.

We might reasonably expect that a considerable proportion of the inorganic phosphate of the internal medium of the cell would occur in association with polyvalent cationic components; but there is at present no justification for assuming that the bulk of it is specifically bound.

It has been stated by Roberts \& Roberts (1950), that the exchange of inorganic phosphate across the surface of Bact. coli is controlled by exchangeadsorption. We might therefore conclude that the mode of uptake and the state of the 'inorganic phosphate' in Bact. coli differs fundamentally from that in $M$. pyogenes. The main objection to the exchange-diffusion hypothesis is the statement of Roberts \& Roberts (1950) and of Roberts \& Wolfe (1952) that Bact. coli is freely permeable to inorganic phosphate. So far, however, this statement has not been supported by experimental evidence amenable to direct comparison with the observations described in this paper. Under the circumstances, it would be advisable to await a parallel examination of the phosphate exchange systems in Bact. coli and $M$. pyogenes by the same group of workers before concluding that they differ fundamentally.

The occurrence of the reciprocal exchange of phosphate across the osmotic barrier of $M$. pyogenes under resting conditions may offer a special opportunity for studying the mechanism whereby inorganic phosphate is passed inward through the osmotic barrier against a concentration gradient when a source of free energy is available. A closer examination of the exchange-diffusion system in resting $M$. pyogenes has therefore been undertaken.

\section{REFERENCES}

Conway, E. J. \& Downey, M. (1950). An outer metabolic region of the yeast cell. Biochem. J. 47, 347.

Green, D. E., Atchley, W. A., Nordman, J. \& Tepley, L. J. (1949). Studies on the cyclophorase system. XII. Incorporation of ${ }^{32}$ P. Arch. Biochem. 24, 359.

HARMan, J. W. (1950). Studies on mitochondria. II. The structure of mitochondria in relation to enzymic activity. Exp. Cell Res. 1, 394.

Kamen, M. D. \& SpIegelman, S. (1948). Studies on the phosphate metabolism of some unicellular organisms. Cold Spr. Harb. Symp. quant. Biol. 13, 151.

Krebs, H. A., Eggleston, L. V. \& Terner, C. (1951). In vitro measurements of the turnover rate of potassium in brain and retina. Biochem. J. 48, 530 .

LUNDEGÅRDH, H. (1945). Absorption, transport and exudation of inorganic ions by the roots. Ark. Bot. $32 \mathrm{~A}, 12,1$.

Mitchell, P. \& Moxle, J. (1951). The glycerophospho-protein complex envelope of Micrococcus pyogenes. J. gen. Microbiol. 5, 981.

Mitchell, P. \& Moyle, M. J. (1953). Paths of phosphate transfer in Micrococcus pyogenes: phosphate turnover in nucleic acids and other fractions. J. gen. Microbiol. 9, $25 \%$. 
Roberts, R. B. \& Roberts, I. Z. (1950). Potassium metabolism in Escherichia coli. III. Interrelationship of potassium and phosphorus metabolism. J. cell. comp. Physiol. 36, 15.

RoBerts, R. B. \& WoLFFe, E. L. (1952). Utilization of labelled fructose-6-phosphate and fructose-1,6-diphosphate by Escherichia coli. Arch. Biochem. 33, 165.

Ussing, H. H. (1947). Interpretation of the exchange of radio-sodium in isolated muscle. Nature, Lond. 160, 262.

(Received 28 March 1953) 